\title{
Anatomia de Euterpe oleracea Mart. (Palmae da Amazônia)
}

\author{
José Elias de Paula ( ${ }^{(7)}$
}

\begin{abstract}
Resumo
Analisada a estrutura anatômica da raíz e folha-axial de espécimes jovens e adultos; da pina, fruto, semente e raque secundário da inflorescência. Detectadas ainda substâncias de reservas, notadamente cristais inulínicos, hemicelulose e lipidios; e corpos silicosos.
\end{abstract}

\section{INTRODUÇÃO}

Euterpe oleracea Mart. é conhecida, vulgarmente, por "Açaí".É uma palmeira de porte médio. Ocorre em toda a Amazônia, notadamente nas regióes pantanosas. A colheita dos frutos se faz durante o ano todo, especialmente, entre maio e junho. Os frutos são muito apreciados, pois, deles preparam-se o famoso "vinho de Açaí" e outros derivados. O palmito é comestível. O fruto e a semente possuem poucas possibilidades de serem usados como matéria-prima na indústria de óleo e gorduras, devidos ao baixo teor de óleo: $7,5-13,5 \%$, na polpa (Altman, 1958). Campos et al. (1951) salientam para a polpa do fruto do "Açaí" $13,4 \%$ de lipídios e $1,25 \%$ de protídios. Por outro lado, Altman (1956) constatou no caroço do "Açaí" 4,34\% de proteínas brutas, 12,26\% de hemicelulose e $34,41 \%$ de celulose. Não consta da bibliografia consultada, nenhuma informação sobre a anatomia do fruto do "Açaí".

\section{MAterial E MÉTOdo}

Utilizamos material fresco e fixado em FAA, FPA e acroleína a $10 \%$, de espécimes frutíferos das cercanias de Belém-Pará e do Parque do Museu Goeldi (MG), Belém, $\odot$ de plântulas e espécimes jovens.

Os cortes histológicos foram executados à mão livre, com gilete, som criostato e com micrótomo rotativo de "Spencer" segundo a técnica da inclusão de material em parafina.

Os compostos fenólicos, lignina e celulose foram identificados por meio do teste metacromático (O'Brien et al., 1964). Quanto à lig- nina, realizamos, também, o teste com floroglucina. Para a celulose e grãos de amilo, fizemos, outrossim, o teste com cloreto de zinco iodado.

A sílica foi detectada pela sua solubilidade no ácido fluorídrico diluído em água, na proporção de $1 / 2$ (Molisch, 1923) e pela insolubilidade nos demais ácidos.

As substâncias proteicas foram identificadas por meio cio reagente de "Schiff". Os cristais de inulina (cristais proteicos) foram detectados com o teste histoquímico seguinte: a) cortes finos de material fixado em álcool a $70 \%$ foram postos no álcool a $70 \%$; b) em seguida na soluçẫo de cloral hidratado $(10 \mathrm{~g}$ de clorai hidratado para $4 \mathrm{ml}$ de água destilada) para clarificar um pouco; c) 1 gota de solução alcoólica de Timol a $15 \%$; d) seguido de 1 gota de ácido sulfurico concentrado ou a $80 \%$. Esta última operação deve ser feita na lâmina porque os cristais de inulina, se for o caso, ficam avermelhados e se dissolvem mais ou menos durante 1 minuto.

Os compostos lipídicos foram identificados com sudan III. A hemicelulose foi detectada pela absorção de vermelho de rutênio, vermelho congo e azul de metileno.

\section{RESUL,TADOS}

\section{Raíz}

(fotos 1 a 5)

Na parte jovem de uma raíz com cerca de $5 \mathrm{~mm}$ de diâmetro, a coifa é bastante longa, com até 2 centímetros e consta de 3 a 6 camadas de células parenquimatosas (fotos 1 e 3 ), particularmente nas raízes subterrâneas. Nas partes mais jovens da raíz, a epiderme consta de células mucilaginosas ou não mucilaginosas, de paredes, moderadamente, espessas; nas partes mais velhas, especialmente nas raízes externas, a epiderme apresenta uma cutícula fina. A exoderme é esclerosada, seguida

(") - Universidade de Brasilia - IB 
de 2 $~ 4$ camadas esclerenquimatosas, as quais constifuem uma bainha esclerenquimatosa. O parênquima fundamental é rico em células mucilaginosas e canais mucilaginosos esquizógenos, sendo mais frequientes na parte externa desse parênquima (foto 3); ocorrem, também, fibras mucilaginosas isoladas e numerosas lacunas (aerênquima), notadamente na porção mais interna desse parênquima, que, em cortes transversais, aparecem alongadas radialmente (fotos 2 e 4). A endoderme é bastante característica, cujas células são pequenas, com vacúolos bem nítidos, algumas delas são mucilaginosas; as células de passagem aparecem isoladas ou aos pares. O periciclo é descontínuo devido aos cordões de fibras pericíclicas. Estelo cilíndrico bem característico, amplo e regular; protoxilema poliarco. Os polos de protoxilema, em geral, com um elemento, raramente dois, sempre acampanhados por fibras, alternados com cordões de floema, cujos elementos crivosos são de diâmetros bem maiores que os des células campanheiras; os vasos lenhosos da perção mais interna do estelo (metaxilema) são mais abundantes, isolados, cuja distribuição obedece orientação circular (fotos 2 e 4), com diâmetro entre 56 e $92 \mu$, sendo mais freqüentes entre 64 e $72 \mu$ (foto 5 ). A parte central do estelo é ocupada por um tecido fibroso, onde se nota a presença de células mucilaginosas e taníferas, e canais são ausentes. As reservas da raíz constituem-se de grãos de amilo, de escassos protídios de natureza semelhante às proteínas descritas no endosperma e de glóbulos lipídicos.

\section{Folha \\ (pina) \\ (fotos 6 a 12)}

Epiderme. Ambas, abaxial e adaxial, são glabras e unisseriadas. Vistas de face, observamos que as células epidérmicas possuem paredes acentuadamente sinuosas (fotos 6 a 8); em geral, as células da epiderme adaxial são largas e, moderadamente, alongadas e estreitas, enquanto as células da epiderme abaxial são longas, moderadamente estreitas. Em secção transversal (foto 9), as células de ambas as epidermes são pequenas, com paredes finas, pectoceluiósicas; são freqüentes células epidérmicas contendo corpos silicosos estrelados. Hipoderme consta de fibras e de células relativamente grandes de paredes pectocelulósicas, provavelmente aquíferas (fotos 9 e 11). $\mathrm{O}$ parênquima paliçádico consta de uma a duas camadas de células. A face abaxial da pina é representada por várias camadas de células amplas, de contorno irregular, algumas com corpos silicosos. Nesse parênquima não ocorrem lacunas (fotos 9 a 11). Os feixes vasculares mais espessos são envolvidos por uma bainha de esclerênquima e essa, por sua vez, é contornada por uma camada de células (bainha fisiológica de Haberlandt) grandes, com parecies finas, pectocelulósicas ( $f$ oto 12); os feixes mais finos são envolvidos, apenas, por uma bainha fisiológica de "Haberlandt" (fotos 9 a 11.). Nos feixes vasculares mais espessos, na parte central, ocorrem 1 a 2 vasos lenhosos grandes, cerca de $320 \mu$ (foto 12).

Estômatos. Ocorrem, unicamente, na epiderme abaxial, dispostos em fileiras discretas moderadamente paralelas, e em certas partes da pına o arranjo dos estômatos ainda é mais irregular (foto 6); os estômatos estão situados sempre ao nivel das demais células epidérmicas; o aparelho estomático é quase totalmente circundado por duas paraestomatócitos, dispostas, paralelamente, ao longo do eixo maior do estômato; em cada polo do estômato há uma célula adjacente, semelhante às outras células comuns da epiderme (foto 7). Vistos em secção transversal, observamos que os estomatócitos possuem espessamento cutinizado na parede que está para a fenda estomática, a ponto de formar, no bordo externo, uma crista que limita a cavidade frontal (foto 9); o lúmem amplo dos estomatócitos, visto em secção transversal polar, apresenta maior diâmetro na direção anticlinal, e na porção mediana tem forma quase triangular; a câmara subestomática é bastante reduzida. Nos cortes transversais, observamos que as paraestomatócitos aparecem um pouco abaixo da crista cutinizada.

\section{Folha-axial}

(fotos 13 e 14)

Em secção transversal, observamos que, em geral, as dobras das pinas muito jovens têm, aproximadamente, forma de " $V$ " ou de 

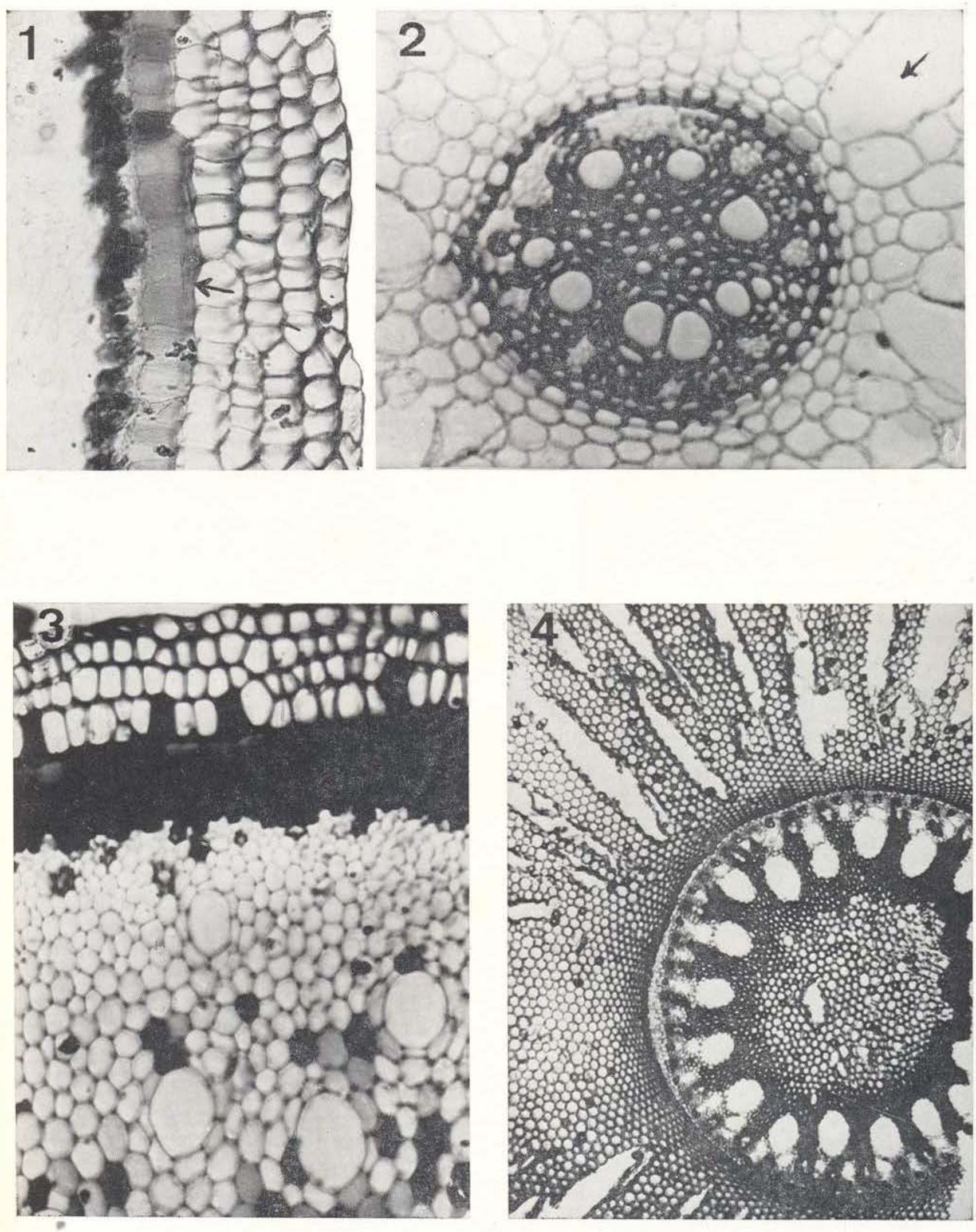

Foto 1 - corte de uma raiz subterrânea mostrando a coifa e epiderme (138x); Foto 2 - corte de uma raiz aérea mostrando o estelo (180x); Foto 3 - corte de uma raiz subterrânea mostrando coifa e canais (120x): Foto 4 - corte de uma raiz subterrânea mostrando estelo e aerênquima (180x) 

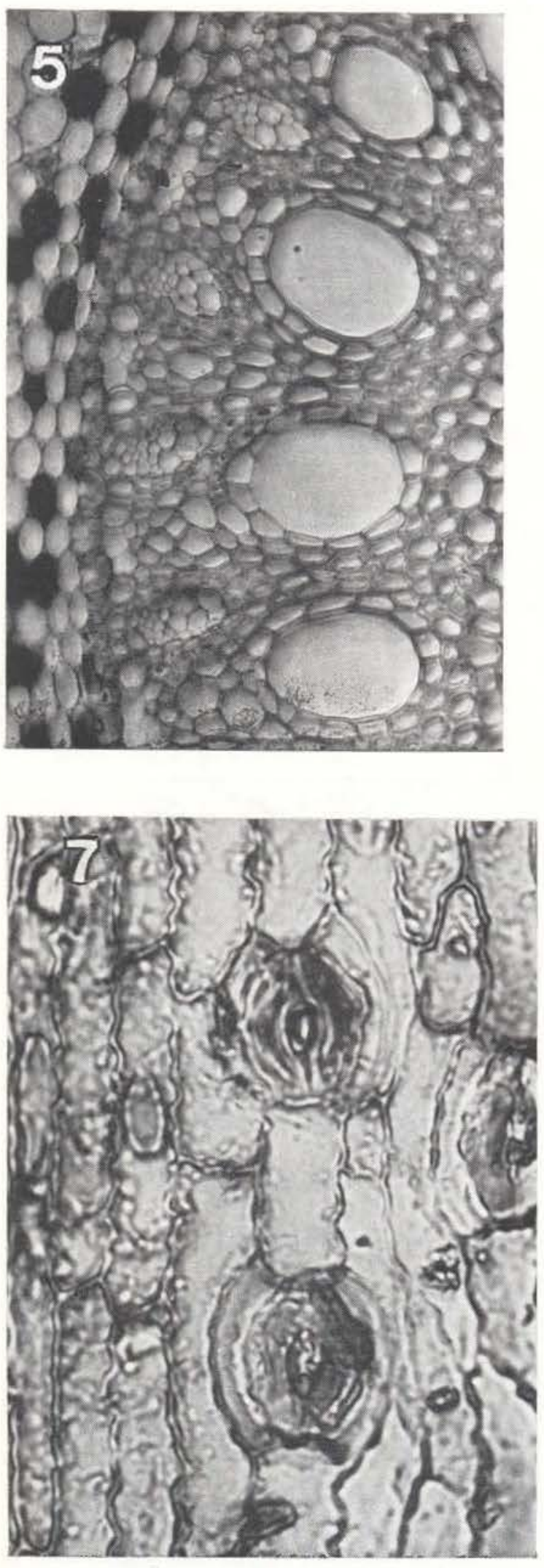
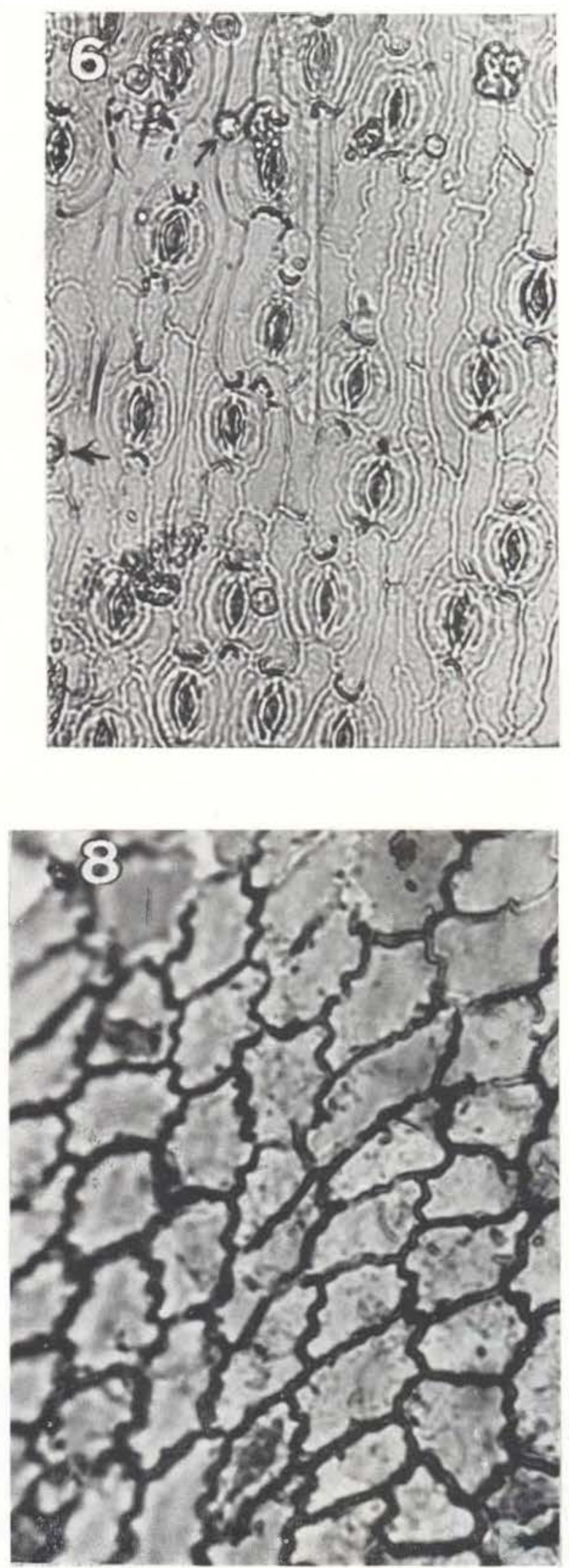

Foto 5 - corte de uma raiz aérea mostrando endoderme e parte do estelo (180x); Foto 6 - epiderme abaxial (250x); Foto 7 - epiderme abaxial (400x); Foto 8 - epiderme abaxial (300x). 

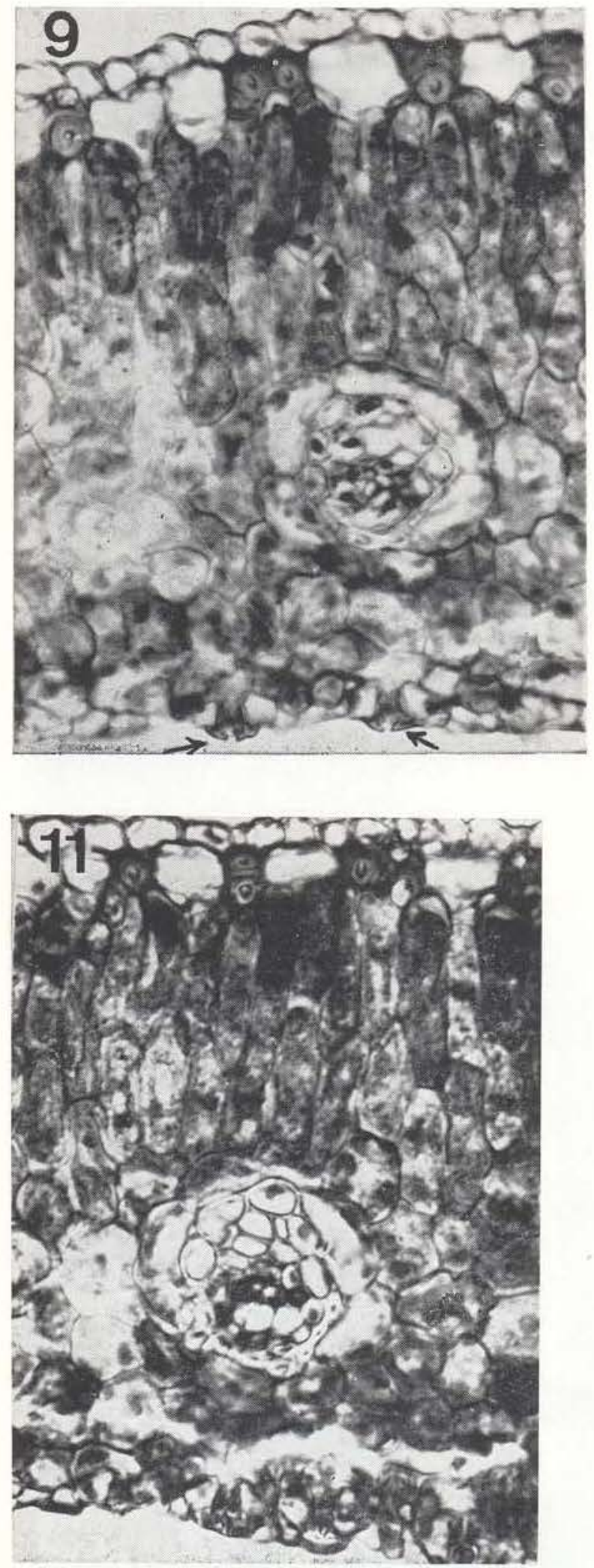
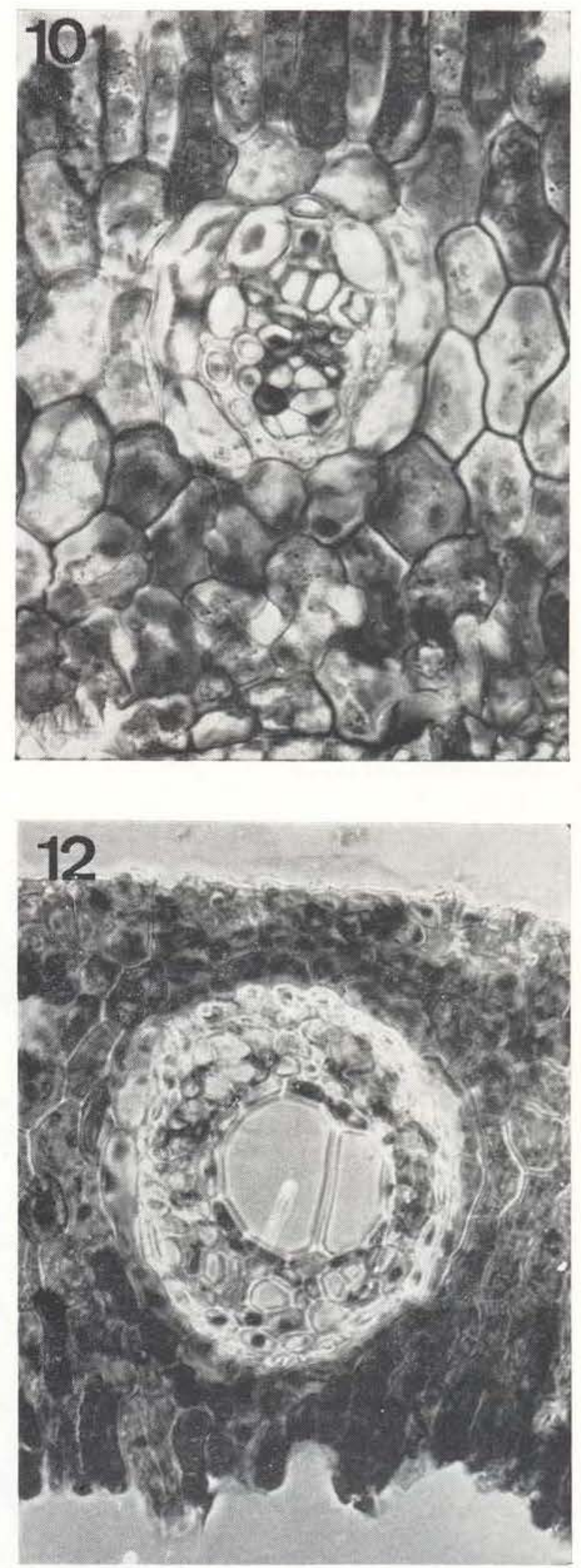

Foto 9 - corte da pina, onde se vêem hipoderme e mesofilo de lacunas $(300 \mathrm{x})$; Foto 10 - corte da pina. onde se vêem um feixe vascular envolvido por uma bainha fisiológica $(300 \mathrm{x})$; Foto 11 - corte da pina mos. trando fibras hipodérmicas $(300 \mathrm{x})$; Foto 12 - parte do mesofilo mostrando um feixe vascular com 2 vasos no centro $(350 \mathrm{x})$. 

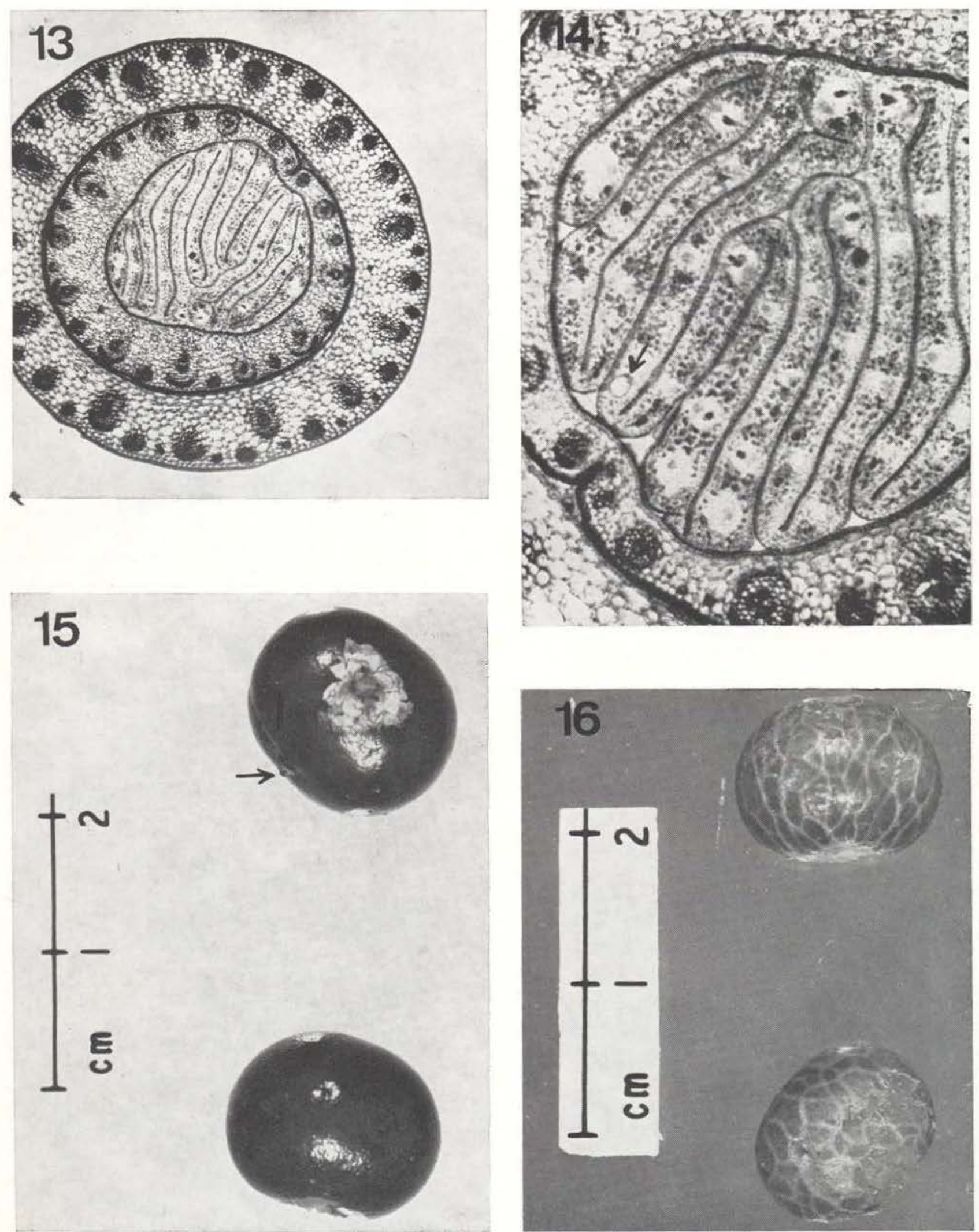

Foto 13 - corte da folha-axial de espécime jovem mostrando as dobras das pinas (86x); Foto 14 - corte da folha-axial de espécime adulto, onde se vêem dobras das pinas e uma bolsa (138x); Foto 15 - fruto mos. trando um "espinho"; Foto 16 - endosperma visto de face. 
"U" (fotos 13 e 14). As pinas das folhas externas (mais desenvolvidas) são ricas em feixes fibrovasculares, as quais são constituídas de um só tipo de parênquima, cujas células, vistas em secção transversal, são semicirculares ou moderadamente ovóides, deixando entre si, espaços intercelulares. Nas plantinhas jovens, esse tecido parenciuimatoso é rico em lacunas, e próximo dos bordos ocorrem, com pouca frequência, bolsas mucilaginosas (fotos 13 e 14). As substâncias de reservas estão representadas por proteínas figuradas, glóbulos lipídicos e poucos grãos de amilo. São freqüentes idioblastos contendo rafídios de oxalato de cálcio.

\section{Fruto}

(fotos $15,16,19$ e 20)

Fruto glabro, globoso, de superfície lisa, de cor violeta, quase negro, quando maduro, com 2,6 a 3 gramas; pericarpo com cerca de $1 \mathrm{~mm}$ de espessura, parcialmente fibroso, destacável da semente. Quando se destaca o pericarpo para o preparo dos derivados (alimentos), parte do tegumento também é removida. Ao remover o pericarpo observa-se, no endocarpo, uma região espessada, moderadamente carnosa, como se fosse uma nervura; esse espessamento parte das proximidades do ponto de união do endosperma com o embrião e se estende até a periferia do fruto, à semeIhança de um espinho (foto 15), pois esta ponta externa é dura, constituída de esclerócitos; nas proximidades do ponto de união do endosperma com o embrião, a referida parte espessada é, parcialmente, carnosa e rica em substâncias de reservas, representadas por grãos de amilo, proteínas figuradas e lipídios. O endosperma é amargo e deixa nas mãos manchas amareladas; apresenta um sulco superficial, horizontal, precisamente na região que está em contato com a porção espessada do endocarpo (foto 17). A superfície do endosperma é toda reticulada, vista de face (fotos 16 e 17); esse retículo representa parte do tegumento da se. mente que é, intimamente, ligado ao endosperma. O embrião é muito pequeno, visível somente com lupa, ou a olho nu durante a germinação (foto 18). Para a preparação do vinho de "Açaí" e outros derivados, o pericarpo é removido juntamente com parte do tegumento, portanto, a parte rejeitada é a semente, cujo endosperma é bastante duro, por isso é chamado de "caroço". O endocarpo do "Açaí" não é lenhoso. Ao contrário do "dendê", "macaíba", "pupunha", "tucumã", o endocarpo é lenhoso, portanto, o "caroço" consta do endocarpo lenhoso e semente. No interior do fruto jovem do "Açaí" há líquuido fisiológico, provavelmente de reserva. No fruto adulto, não há mais o referido líquido e o espaço acumulador do liquuido foi ocupado pelo endosperma.

Pericarpo (fotos 19 e 20). Do ponto de vista estrutural, distinguem-se, no pericarpc, as seguintes partes: a) epiderme externa constituída de células de paredes, moderadamente, finas. pectocelulósicas, sendo que as paredes -periclinais externas são relativamente espessas e cutinizadas; b) parênquima fundamental externo, representado por várias camadas de células, em geral, comi maior diâmetro tangencial, de pareres finas, pectocelulósicas, e que, na maturação, a maioria dessas células se diferencia em esclerócitos; c) zona mediana esclerenquimatosa, constituída de várias camadas cle braquiesclerócitos; d) parênquima fundamental interno, representado por células com maior diâmetro tangencial, de paredes finas, pectocelulósicas, deixando entre si, espaços intercelulares. Nesse parênquima estão situados os feixes vasculares e que, no fruto adulto, esses feixes são envolvidos por uma bainha de esclerênquima; e) epiderme interna (fotos 19 e 24), constituída de células de diâmetro pequeno, de paredes finas, pectocelulósicas. O pericarpo possui poucas substâncias de reservas, as quais são representadas por protídios que se apresentam sob a forma de pequenos glóbulos e cristalóides proteicos de inulina, por pequenos glóbulos lipídicos e raros grãos de amilo. O pericarpo é rico em corpos silicosos (foto 20).

Tegumento (fotos 23 e 24). Consta de várias camadas de células, sendo que a porção mais interna é rica em substâncias de reservas e a parte externa é representada por células de paredes bastante espessas, pontuadas $e$ lignificadas. O tegumento emite projeções no endosperma, com 8 a 13 camadas de células de largura, em geral profundas (foto 23); as células dessas projeçōes são de paredes finas, pectocelulósicas, ricas em substâncias de reservas. 

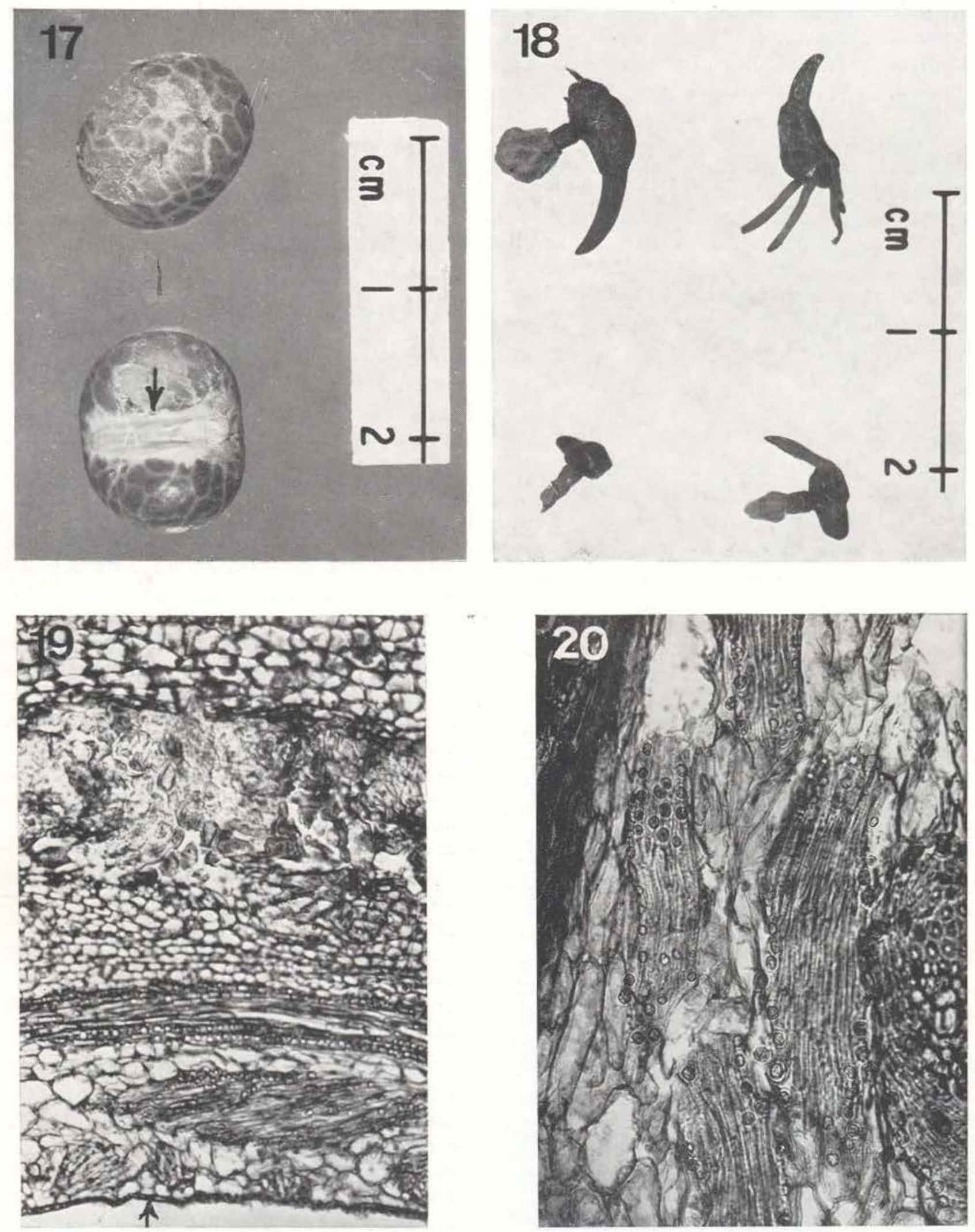

Foto 17 - endosperma visto de face mostrando um sulco; Foto 18 - embrião em 4 fases da germinação. Foto 19 - pericarpo em corte transversal, a seta indica a epiderme interna (120x); Foto 20 - parte do pericarpo mostrando corpos silicosos (138x). 

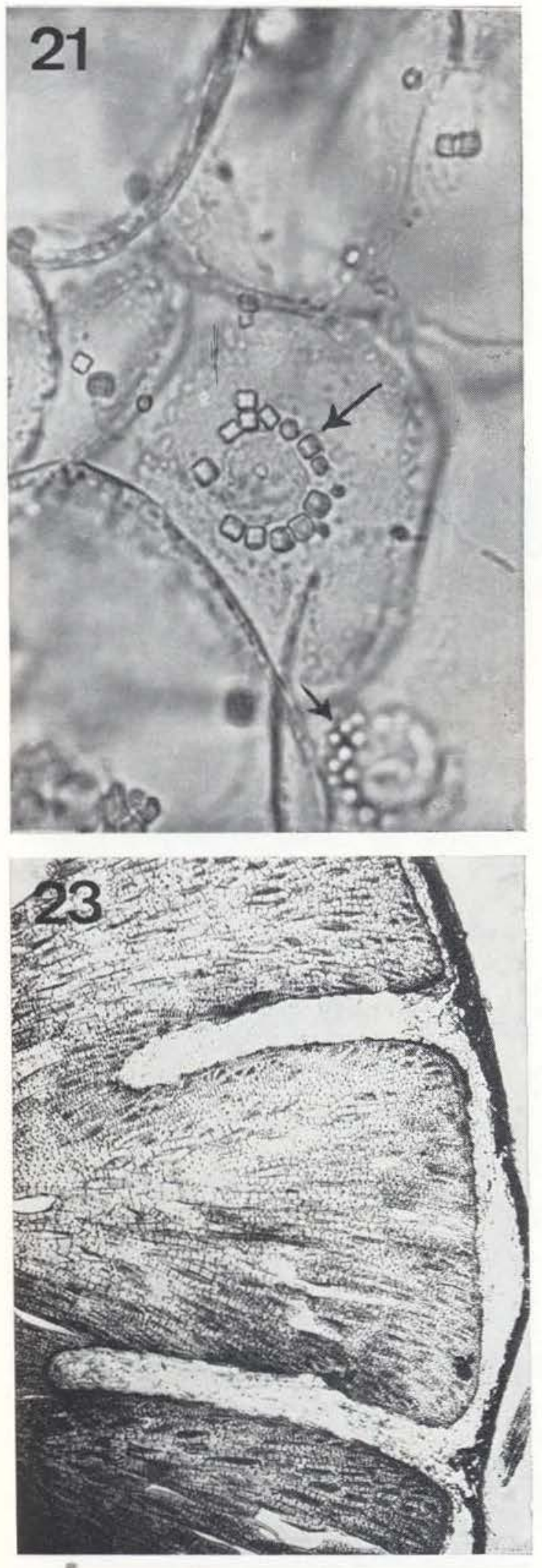
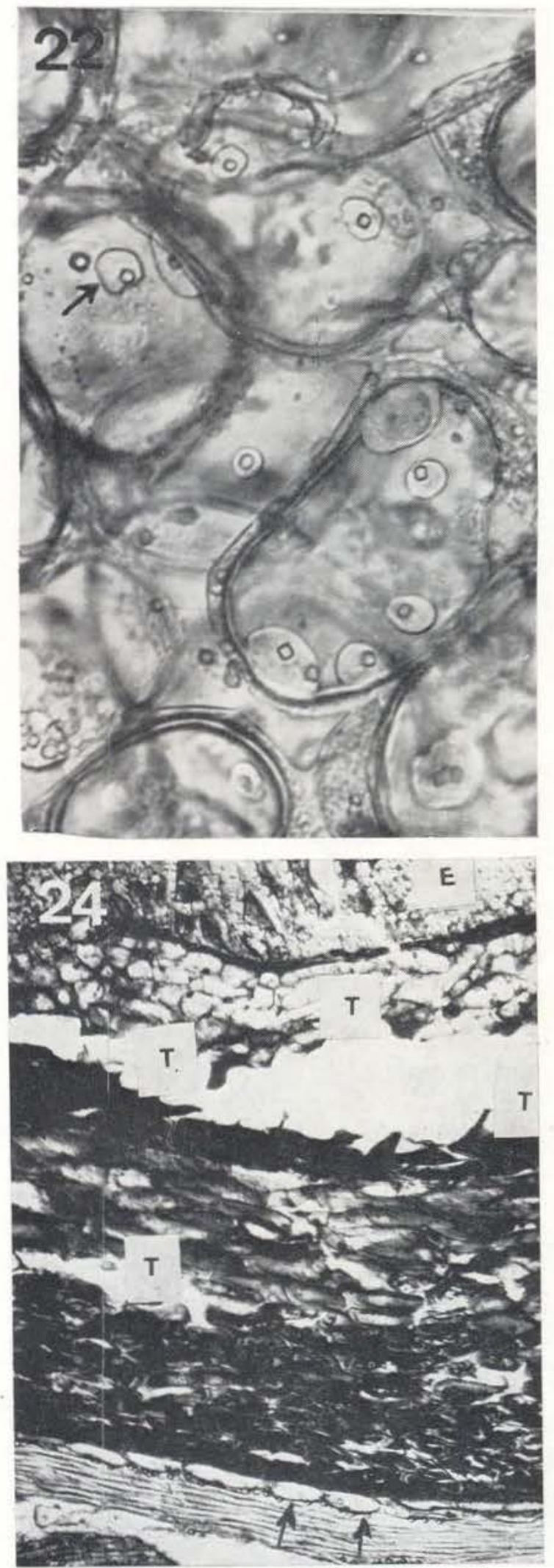

Foto 21 - parte do endosperma mostrando cristaloi des inulínicos (650x); Foto 22 - endosperma jovem mostrando glóbulos proteicos $(650 \mathrm{x})$; Foto 23 - parte do tegumento penetrado no endosperma (100x); Foto 24 - as setas indicam epiderme interna do pericarpo; t, tegumento; e, endosperma (138x). 

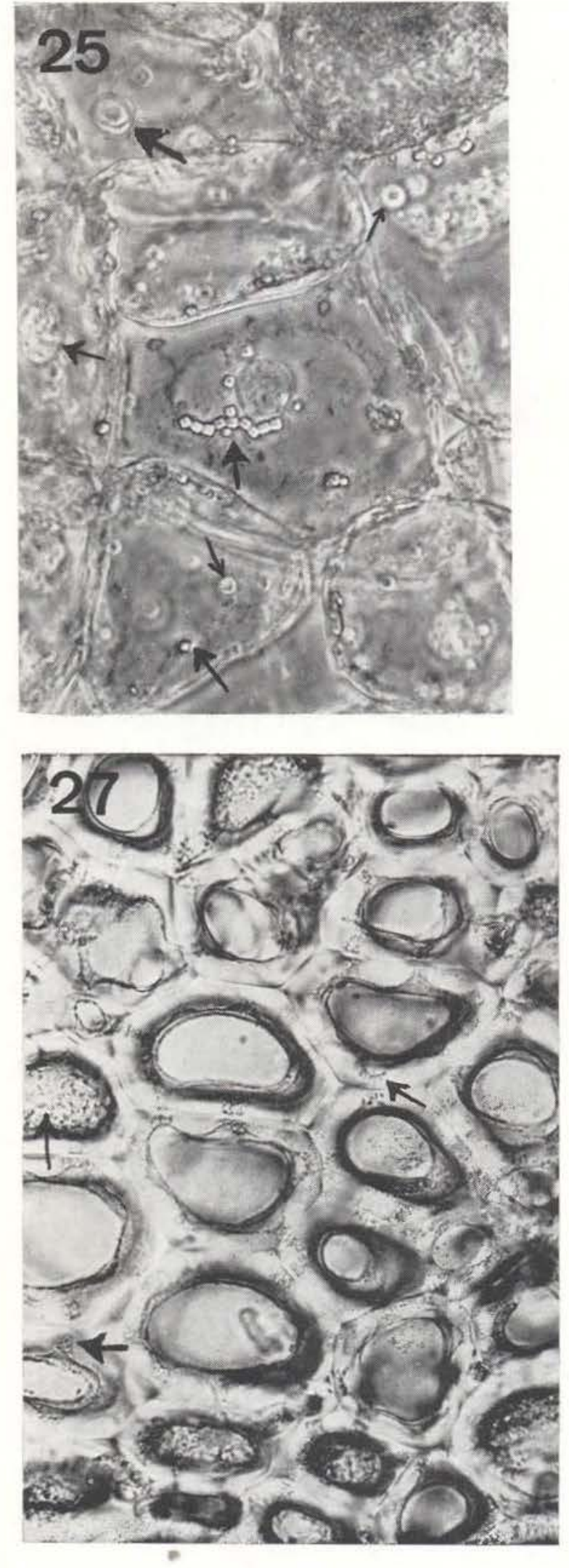
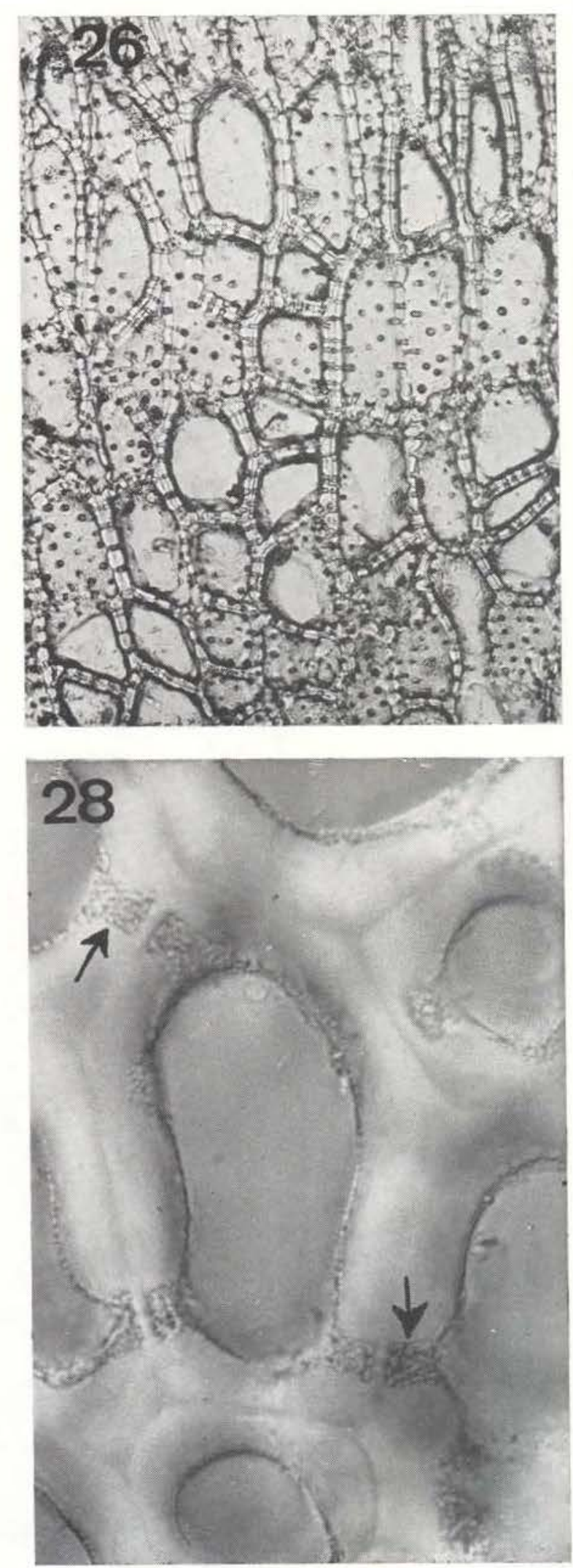

Foto 25 - parte do endosperma mostrando cristaloides inulínicos (520x); Foto 26 - endosperma quase maduro $(280 \mathrm{x})$; Foto 27 - endosperma maduro $(350 \mathrm{x})$; Foto 28 - células endospérmicas mostrando paredes com áreas de pontuações (890x). 

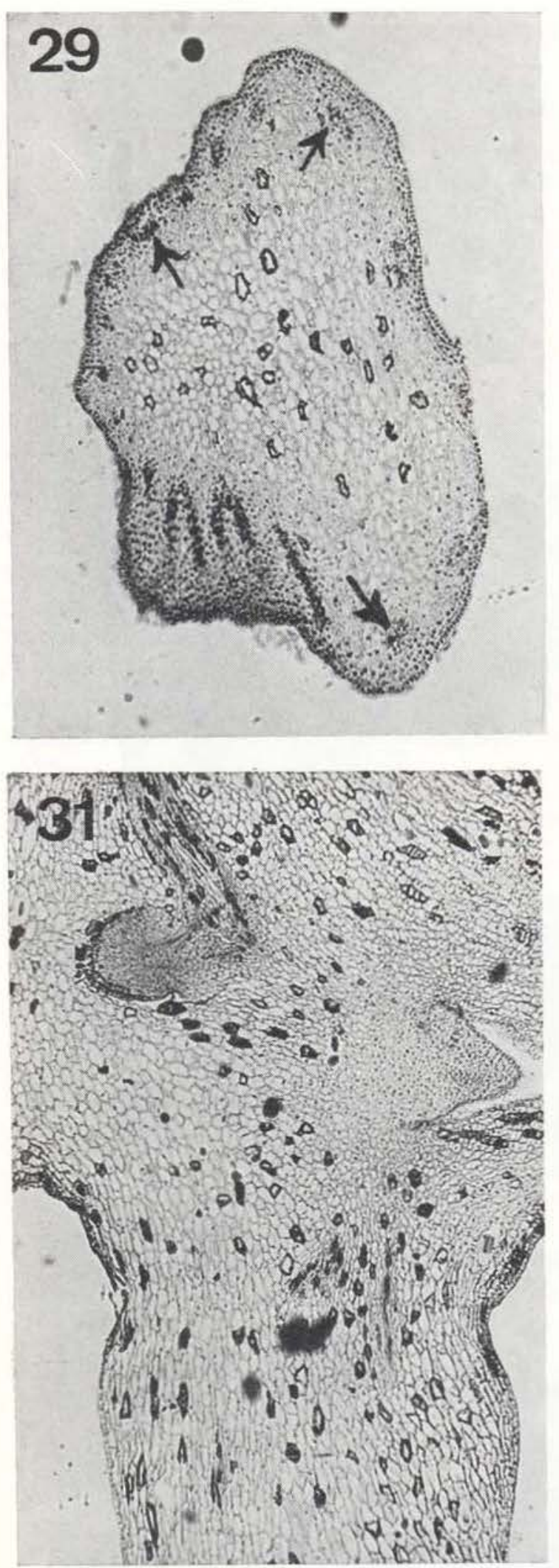
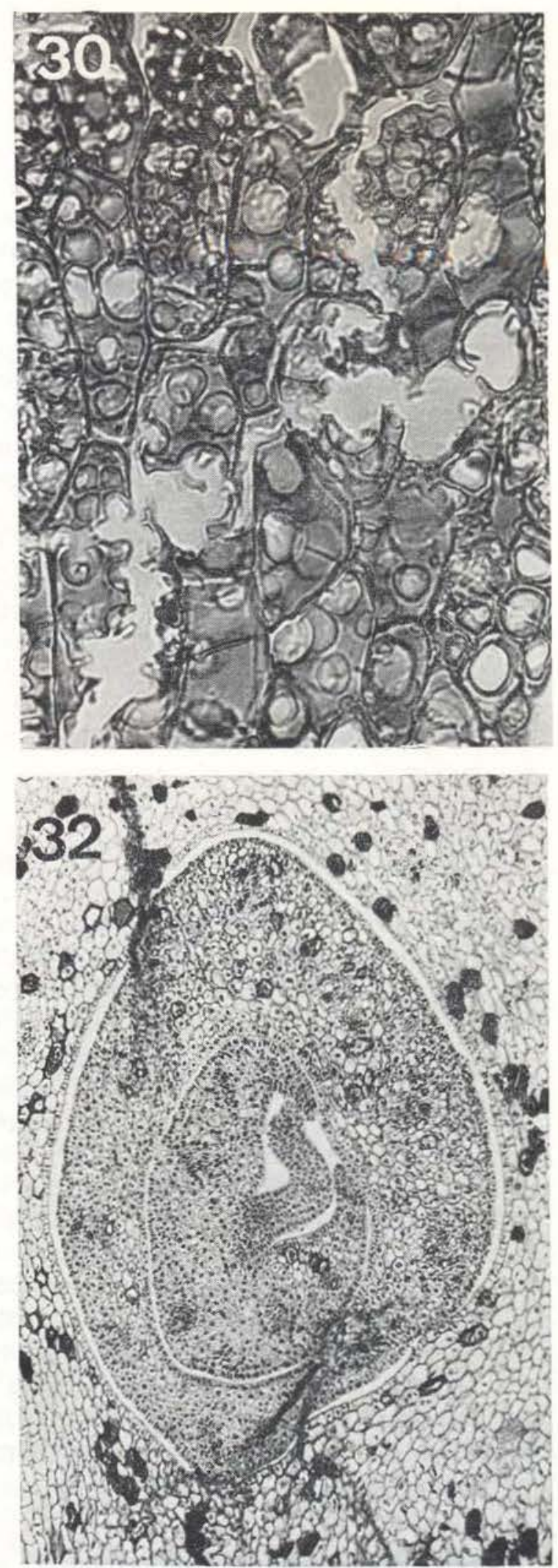

Foto 29 - cotilédone em corte transversal (100x); Foto 30 - parte do cotilédone com grãos de amilo ( $350 \mathrm{x}$ ); Foto 31 - embrião em corte longitudinal (100x); Foto 32 - embriãc em corte transversal (100x), 
Endosperma. Na semente jovem, as células são de paredes finas, pectocelulósicas (fotos 21 a 22). Nessa fase, as substâncias de reservas são abundantes, quase todas proteicas, havendo, porém, poucas gotículas lipídicas e raros grãos de amilo. Conforme os testes histoquímicos que realizamos, a maior parte dos carbohidratos se transforma em proteínas cristalóides proteicas, do tipo inulina, que se apresentam sob as formas tetraédricas e de pequenos esferocristais (fotos 21 e 22). Nessa fase jovem é comum massa de carbohidratos com cristalóides, os quais aparecem isolados ou em grupos, cujo arranjo obedece uma orientação circular (fotos 21,22 e 25). No endosperma maduro, as células endospérmicas são de paredes bastante espessas, constituídas de celulose e hemicelulose, dotadas de pontuações (fotos 26 e 28); nessa fase adulta, as substâncias de reservas são quase todas lipídicas $\mathrm{e}$ hemicelulósicas. Observamos, em muitas dessas células, porções citoplasmáticas granulosas com gotículas lipídicas e áreas de pontuaçōes, provavelmente com plasmodesmas (foto 28).

Embrião (fotos 29 a 32). Como já salienta. mos, o embriāo de Euterpe oleracea Mart. é muito pequeno. O cotilédone, visto em corte transversal, apresenta secção semicircular, circular e oblonga, dependendo da região, com extremidade sempre irregular, às vezes tri ou bilobada, extremamente ligada ao endosperma (foto 29); os feixes vasculares são em número que varia entre 9 e 25 cordöes de protoxilema. A maior parte das substâncias de reservas é representada por grãos de amilo (foto 30 ), ha. vendo. portanto, poucas gotículas lipídicas e proteicas. As células protodérmicas são grandes, com maior diâmetro radical, sempre com núcleo grande bem distinto. A foto 31 ilustra um corte tangencial do eixo embrionário, onde se observam primórdio radicular e foliar. A foto 32 mostra corte transversal do embrião, em fase de germinação, onde se vêem primór dios foliares bastante diferenciados.

\section{Raque secundário da inflorescência} ?

A foto 33 representa parte do raque cortado transversalmente. Os feixes fibrovasculares são numerosos, de espessura variada, dis-
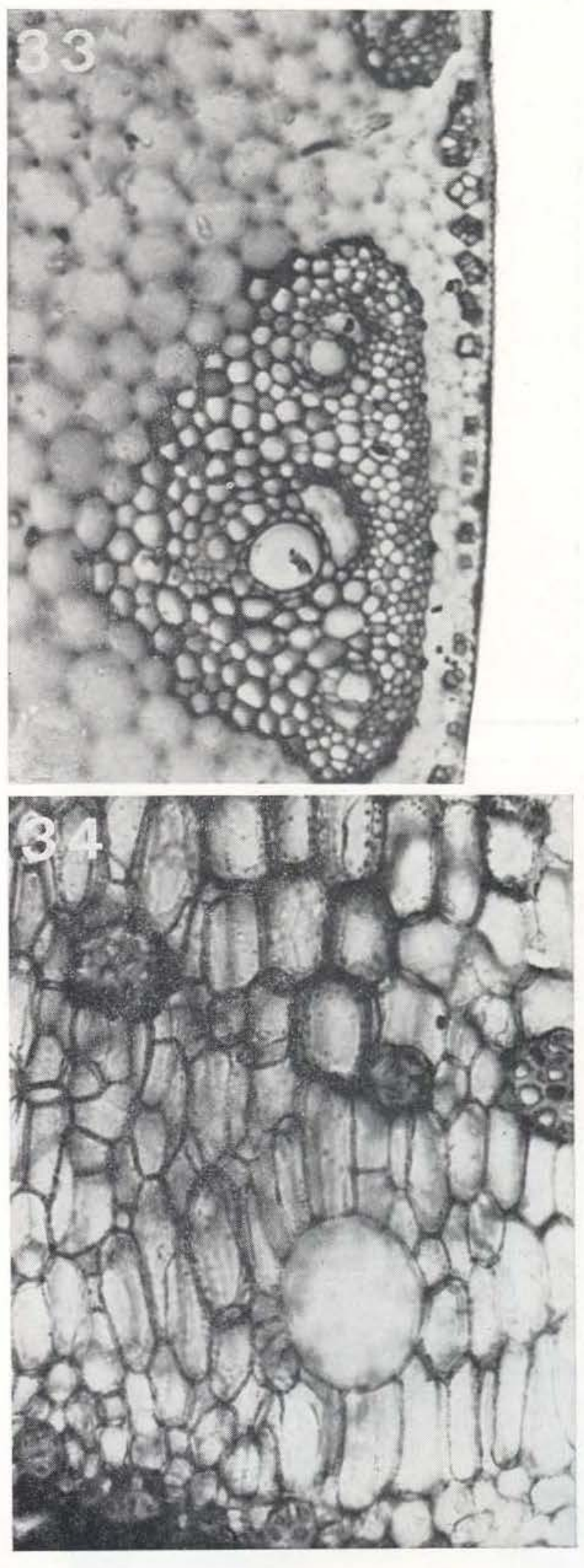

Foto 33 - parte do raque secundário da inflorescência (168); Foto 34 - corte tangencial do raque ao nível do ponto de inserção do fruto mostrando uma bolsa (138x), 
tribuidos atactostelicamente. Na porção mais externa do raque, em geral, se diferencia uma bainha fibrosa. A foto 34 ilustra uma secção tangencial do raque ao nível do ponto de inserção do fruto no raque, onde se observa uma bolsa relativamente grande. Provavelmente, essa bolsa está relacionada com a passagem do líquido para o interior do fruto, se é que o líquido existente no interior do fruto jovem se forma ou se acumula, por algum tempo, nos tecidos contíguos ao ponto de inserção do fruto.

\section{Discussão}

Comparando a estrutura das epidermes abaxial e adaxial e dos estômatos de um espécime de Euterpe oleracea Mart., (estudado por Tomiinson, 1961) com a dos espécimes por nós estudados, notamos diferenças estruturais consideráveis. Como sejam: as paredes das células de ambas as epidermes, vistas de face são bastante sinuosas, nos espécimes aqui estudados; no material que estudamos, os espessamentos cutinizados dos estomatócitos, vistos em cortes transversais, só apresentam crista no bordo externo, enquanto que, a figura $3 \mathrm{c} d a$ página 375 apresentada pelo citado autor, tem cristas nos bordos interno e externo. Um caráter marcante das pinas de Euterpe oleracea é a ausência de parênquima lacunoso no mesćfilo. Em Copernicia prunifera (Miller) H. E. Moore, os estômatos possuem quatro células subsidiárias (Arraes et al. 1966), enquanto que os estômatos de Euterpe oleracea possuem duas células subsidiárias (paraestomatócitos) típicas. Um outro caráter marcante de Euterpe oleracea é a distribuição irregular de seus estômatos. A presença de lacunas aeríferas no parênquima fundamental da raíz, constitui um caráter evidente de certas espécies de Palmae, como é o caso de Euterpe oleracea, Nypa truticans, Pinanga sp. e Phoenix reclinata. Do mesmo modo sâo os canais mucilaginosos que caracterizam muitc bem Doemonorops grandis e Euterpe oleracea.

Arraes (1963) salienta, no endosperma de Orbignya martiana B. Rodr. células com paredes espessas e pontuadas; substâncias lipídicas, hemicelulósicas e proteicas figuradas sob a torma de grânulos cristalóides. No endosperma jovem de Euterpe oleracea, as substân- cias de reservas são quase que somente proteicas, figuradas sob a forma de grânulos ou cristalóides tetraédricos e esféricos, de inulina, enquanto que no endosperma maduro, as substâncias de reservas são representadas por lipídios e hemicelulose, na sua maior parte. As formas e o arranjo circular dos referidos cristalóides são semelhantes as dos cristalóides que ocorrem na "cana-de-açúcar".

\section{Conclusões}

Do nosso estudo destacamos os dados mais expressivos :

Raiz - caracterizada pela presença de lacunas aeriferas e canais esquizógenos mucilaginosos, no parênquima fundamental; coifa ionga; estelo cilíndrico, bem delimitado; parte central do estelo ocupado por tecido fibroso.

Pina - Epidermes abaxial e adaxial glabras, constituídas de células com paredes sinuosas; estômatos distribuídos irregularmente; aparelhc estomático circundado por duas paraestomatócitos típicas, e com câmaras subestomáticas pequenas; mesófilo dorsiventral e carente de lacunas.

Fruto - Pericarpo parcialmente fibroso, rico em corpos silicosos e pobre em lipídios, protídios e grãos de amilo; endocarpo não lenhosc; tegumento intimamente ligado ao endosperma emitindo projeções no endosperma; endosperma reticulado, visto de face, mais ou menos rijo quando maduro, rico em cristalóides proteicos de inulina, na fase jovem e na matu. ração é rico em lipídios; paredes celulares endospérmicas bastante espessas, constituídas de celulose e hemicelulose. Embrião pequeno; cotilédone semicircular, circular e oblongo, em secção transversal, rico em grãos de amilo e pobre em cristaloides inulínicos.

Folha-axial - Polifenois escassos; cristalóides proteicos abundantes; idioblastos contendo rafídios de oxalato de cálcio, freqüentes especialmente nas partes mais jovens.

\section{AgRAdecimentos}

Ao Dr. Paulo B. Cavalcante, Sr. Milton G. da Silva, do Museu Goeldi; Dr. Byron W. P. de Albuquerque, do Instituto Nacional de Pes- 
quisas da Amazônia (INPA); Dr. Ezechias Paulo Heringer, Dra. M. Artemísia Arraes Hermans, da Universidade de Brasília; Dr. J. Luiz de Hamburgo Alves, da Universidade Federal de Pernambuco; e ao Sr. Nestor Bezerra de Lima, do Laboratório de Fotodocumentação Científica da Universidade de Brasília. A eles, os nossos agradecimentos pela colaboração que nos foi prestada para a execução deste trabalho.

\section{SUMMARY}

This paper is a contribution to the study of the anatomy of Euterpe oleracea Mart., commonly known as "Açai".

Among the principal results of this investigation I point out the following: presence of cuticle; mucilaginous schizogenous canals, and aerenchyma in the root; palisade parenchyma with 1-2 layers; lacunose parenchyma absent in the mesophyll of the pinna; silica-bodies present in the epidermal cells of the pinna; cell walls of the epidermal cells sinuous; stomata not in distinct rows; terminal subsidiary cells not differentiated from other €pidermal cells; endocarp rich in silica-bodies, and poor in oil and protein; young endosperm rich in protein and inulin crystals, mature endosperm rich in oils.

\section{BIBLIOGRAFIA CITADA}

Altman, R.F.A.

1956 - O caroço do Açaí (Euterpe oleracea Mart.). Bol. Téc. Inst. Agro. Norte, Belém, 31: 109-111.

1958 - A exploração industrial de sementes oleaginosas amazônicas. Publ. INPA. série: Química, 4: 5-24.

ARraes, M.A.B.

1963 - Estudo preliminar na anatomia do fruto do Babaçu. An. Acad. Bras. Ci., Rio de Janeiro, 35(2):viii-ix, (Resumo das comunicações)

ARraes, M. A. B;; Machado, R.D. \& Nepomuceno, V.A. 1966 - Sobre a anatomia da folha da Carnaubeira Copernicia prunifera (Miller) $\mathbf{H}$. E. Moore. An. Acad. Bras. Ci., Rio de Janeiro, 38(1) : 73-82.

Campos, F.A.M.; Pechnik, M. \& Siguetra, R. DE

1951 - Valor nutritivo de frutas brasileiras Arq. Bras, Nutr, Rio de Janeiro, 8(2) : 99-161.

MOLISCH, $\mathrm{H}$.

1923 - Mikrochmie der pflanzen. Wien. 438p.

O'BRIEN, T.P.; Fider, N. \& CULLy, M.E.

1964 - Polychromic staining of plant cell by Toluidine blue. Protoplasma, Cambridge, $59: 367-373$.

TOMLINSON, P.B

1961 - Anatomy of the monocotyledons. Oxford, University Press. 453p. 